ОСОБЛИВОСТІ ОРГАНІЗАЦІЇ ПРОФЕСІЙНОЇ ПІДГОТОВКИ МАЙБУТНІХ УЧИТЕЛІВ ІНОЗЕМНОÏ МОВИ В НІМЕЧЧИНІ НА ЗАСАДАХ МІЖКУЛЬТУРНОГО ПІДХОДУ

\title{
THE PECULIARITIS OF ORGANIZATION OF THE PROFESSIONAL TRAINING OF FUTURE FOREIGN LANGUAGE TEACHERS IN GERMANY ON THE BASIS OF THE INTER-CULTURAL APPROACH
}

Стаття присвячена дослідженню проблеми організації профресійної підготовки майбутніх учителів іноземної мови в Німеччині в умовах формування інтеркультурного суспільства під дією чинників глобалізації, міжнародної міграції та євроінтеграції. На основі конкретизації загальноєвропейських вимог виокремлено переваги модернізації профресійної підготовки майбутніх учителів іноземної мови в Німеччині на основі впровадження настанов міжкультурного підходу. З'ясовано провідні форми (міжкультурний тренінг) і методи (контрактивний, дистрибутивний, інтерактивний, колаборативний) організації профресійної підготовки майбутніх учителів іноземної мови на засадах міжкультурного підходу. Продемонстровано, що міграція і зростання культурного розмаїття стали розглядатися прогресивно мислячими вченими Німеччини не як ризик, який слід долати, а як реальні ресурси розвитку особистості сучасного європейця шляхом визнання загальнолюдських цінностей як універсальних. Уточнено, що реалізація засобів міжкультурного підходу у процес організації професійної підготовки майбутніх учителів іноземної мови в Німеччині сприяє набуттю ними якостей полікультурної багатомовної особистості як медіатора культур у сфрері міжкультурноі іншомовної освіти. Для цього навчальними планами спеціальності "Interkulturelles Lernen" передбачено вивчення майбутніми вчителями іноземної мови питань, які стосуються способів подолання лінгвістичних проблем у системі міжкультурної освіти, особливостей організації процесу академічної та соціально-психологічної адаптації дітей іноземців до нових реалій життя в чужій країні. Майбутніх учителів іноземних мов залучають до дослідження й оволодіння способами роботи з учнями-мігрантами, враховуючи два контексти: соціокультурну інтеграцію іноземних дітей у культуру Німеччини як країни перебування; організацію роботи з підтримки культурних і мовних зв'язків з країною походження учнів-мігрантів.

Ключові слова: професійна підготовка, майбутні вчителі іноземної мови, міжкультурний підхід, медіатор культур, міжкультурна освіта.

The article is devoted to researching on the issue of organization of the professional training of future foreign language teachers in Germany under the conditions of formation of the inter-cultural society as impacted by certain factors, such as: globalization, international migration as well as Euro-integration. Thus, on the basis of concretization of the general European requirements, we have attempted to emphasize the advantages of modernization of the profes sional training of future foreign language teachers in Germany on the basis of implementation of the inter-cultural approach. In addition, we have managed to single out the leading forms (the inter-cultural training) and methods (the contractive, the distributive, the interactive, the collaborative) of organization of the professional training of future foreign language teachers on the basis of the inter-cultural approach. On top of that, we have managed to illustrate that the migration and increase in the cultural diversity are already considered by a number of progressively-thinking scholars in Germany not as a challenge which needs to be tackled, but rather as a powerful resource of formation of a personality by means of acceptance of the universal human values. Besides, we have pointed out that the realization of the methods of the inter-cultural approach into the process of organization of the professional training of future foreign language teachers in Germany, tends to promote the latter's traits, which are essential to that one of a multi-cultural and multi-lingual personality who is capable of acting as a cultural mediator in the sphere of the inter-cultural foreign language education. For that matter, the curricula included in the speciality "Interkulturelles Lernen" have envisaged studying by future foreign language teachers of certain matters, which pertain to the ways and methods of resolving various linguistic issues in the framework of the inter-cultural education, the intricacies of organization of the process of academic and social-psychological adaptation of children-migrants for the life challenges they may face whilst living in a foreign country. Thus, future foreign language teachers are generally enrolled in the relevant research as well as in the educational process of mastering certain activities related to interaction with children-migrants, taking into consideration 2 contexts: the socio-cultural integration of children-migrants into the German culture being their contemporary country of residence; the organization of activities focused on enforcement of the cultural and linguistic links with their country of origin.

Key words: professional training, future foreign language teachers, inter-cultural educational approach, cultural mediator, inter-cultural education.
Постановка проблеми у загальному вигляді. В умовах поглиблення глобалізації, стрімкого зростання обсягів міжнародних комунікацій та інтерналізації міграції, а також значного розширення техніко-економічної, соціокультурної й науковоосвітньої інтеграції, які спричинили появу ознак нового - інтеркультурного європейського суспільства, значно актуалізуються проблеми, пов'язані 3 подальшою модернізацією професійної підготовки вчителів іноземних мов на засадах найсучасніших підходів, серед яких міжкультурний підхід посів чільне місце. 
Суттєво, що концептуальні засади модернізації та відповідного ресрормування європейських національних систем профеесійної підготовки вчителів іноземних мов окреслені в програмних документах і звітах Європейської комісії. Серед них провідними вважаються такі: «Європейські керівні принципи підготовки і розвитку педагогів професійної освіти» (Common European Principles for Teacher Competences and Qualifications, 2005), «Забезпечення якості педагогічної освіти в Європі» (Quality Assurance in Teacher Education in Europe, 2006), «Європейська рамка кваліфрікацій для навчання впродовж життя» (The European Qualifications Framework for Lifelong Learning, 2008), «Ключові компетентності вчителя: вимоги та розвиток» (Teachers' Core Competences: Requirements and Development, 2011), «Покращення викладання в Європі» (The European Qualifications Framework for Lifelong Learning Strengthening Teaching in Europe, 2013), «Підтримка розвитку компетентностей вчителів» (Supporting Teacher Competence Development, 2013), «Підтримка освітян» (Supporting Teacher Educators, 2013), «Освіта та навчання 2020» (Education and Training 2020).

3 огляду на зазначене вище, варто підкреслити, що значний позитивний досвід 3 модернізації професійної підготовки вчителів іноземних мов напрацьовано в Німеччині, де на державному рівні забезпечується їх гідний соціальний статус і якісна іншомовна педагогічна освіта, сорормовано міцні академічні традиції та високі стандарти (7-ий кваліфікаційний рівень Європейської рамки кваліфрікацій). Особливо цікавою видається інноваційно-педагогічна практика викладачів німецьких університетів та вищих педагогічних шкіл 3 організації профресійної підготовки вчителів іноземних мов на засадах міжкультурного підходу, що в українському науково-педагогічному дискурсі висвітлено не досить.

Аналіз останніх досліджень і публікацій. Кардинальні зміни у структурі сучасного суспільства, перетворення його на багатокультурне і полілінгвальне спонукали німецьких учених не тільки до поглибленого дослідження особливостей міжкультурної комунікації (Ю. Больтен, Е. Боссе, М. Даті, Е. Кінаст, С. Ратьє) й перегляду ролі іноземних мов у системі освіти, чому були присвячені їхні праці ще наприкінці XX століття, але й до розробки різних концепцій багатомовного навчання (Г. Ноймана, Г. Крумма, Ф. Майснера, Б. Хуфайзен) й міжкультурної освіти (Р. Канел, С. Майер, А. Шейтза). Вчені наголошують на важливості профресійного становлення майбутніх учителів іноземних мов не тільки як проєвропейськи налаштованих фрахівців з освітньої міжкультурної комунікації, але й як полікультурних багатомовних особистостей - медіаторів культур шляхом формування ознак профресіоналізму їхньої діяльності як дослідників, проєктувальників, організаторів, диспетчерів та менеджерів у сфрері міжкультурної іншомовної освіти.

Виділення не вирішених раніше частин загальної проблеми. Згідно з положеннями документа «Забезпечення якості педагогічної освіти в Європі», професія вчителя іноземної мови має розвиватися в європейському просторі як:

- висококваліфрікована профресія: високоякісні освітні системи характеризуються тим, що всі вчителі іноземної мови отримують освіту у вищих навчальних закладах;

- просресія, що вимагає неперервного навчання: підвищення кваліфікації вчителів іноземної мови має тривати впродовж усієї їхньої педагогічної кар'єри й підтримуватися на національному, регіональному та місцевому рівнях. Учителі іноземної мови мають усвідомлювати важливість здобуття нових знань і бути здатними до новаторства і використання фрактичних даних в їхній роботі. Вони мають бути повністю залучені до процесу навчання впродовж життя, бути здатними розвиватися й адаптуватися протягом профресійної діяльності, що має визнаватися і підтверджуватися в будь-якій освітній системі;

- мобільна професія: мобільність має бути центральним компонентом основної освіти та навчання впродовж життя. Вчителі іноземної мови мають заохочуватися до стажувань в європейських країнах для професійного розвитку. Статус учителів іноземної мови, які проходять стажування за кордоном, має визнаватися в обох країнах: у рідній країні та країні, у якій вони проходять стажування. Має існувати можливість мобільності в межах різних рівнів і різних педагогічних спеціальностей;

- професія на основі партнерства: навчальні заклади, що надають професійно-педагогічну освіту вчителям іноземної мови, мають співпрацювати зі школами, роботодавцями й установами підвищення кваліфікації. Потрібно заохочувати зацікавленість та участь учителів іноземної мови у дослідженнях та інноваційних процесах, щоб вони відповідали потребам інсрормаційного суспільства. Вчителі іноземної мови мають працювати в освітніх організаціях, у яких вони можуть представити свої кращі досягнення, а також вивчити кращий досвід колег. Вищі навчальні заклади мають гарантувати, що знання, які вони надають учителям іноземної мови, базуються на кращих практиках [6, с. 19-21].

Як результат, сучасний учитель іноземної мови мусить набути таких фрахових компетенцій: працювати з різними видами знань, технологіями та інфрормацією; співпрацювати з іншими - учнями і студентами, колегами, соціальними партнерами; діяти на місцевому, регіональному, національному, європейському та глобальному рівнях тощо 
[5, с. 41]. Набуттю зазначених компетенцій сприяють технології професійної підготовки майбутніх учителів іноземних мов, побудовані на засадах міжкультурного підходу [9].

Мета статті - виявити особливості організації профресійної підготовки учителів іноземних мов у Німеччині на засадах міжкультурного підходу.

Виклад основного матеріалу. Вивчення праць німецьких науковців доводить, що професійна підготовка майбутніх учителів іноземних мов переважно здійснюється в університетах Німеччини на засадах єдності компетентнісного, практико-орієнтованого й міжкультурного підходів [2, с. 270]. Поштовхом до впровадження концептуальних засад міжкультурного підходу з початку нового століття стало стрімке зростання обсягів трудової й освітньої імміграції, а також введення спеціальності «Міжкультурна комунікація» в Мюнхенському університеті у 1989 р. [1, с. 181]. Ґрунтуючись на досвіді викладання міжкультурної комунікації в США, викладачі університету розробили власні навчальні програми, що базуються на матеріалах етнології, фрольклористики та лінгвістики. Протягом наступних двох десятиліть мюнхенська школа зробила значний внесок у розвиток і подальше становлення міжкультурної комунікації як академічної дисципліни. Програма міжкультурної освіти і виховання, розроблена Мюнхенським університетом, визнана однією з найкращих освітніх програм з міжкультурної комунікації в усьому світі.

Як зазначає А. Шейтза, вивчення іноземних мов $€$ одним із найбільш пріоритетних напрямів міжкультурної освіти у німецьких закладах вищої освіти. При цьому студенти будь-якої спеціальності, особливо майбутні вчителі іноземних мов, також мають певні можливості щодо вивчення теорії та практики міжкультурної комунікації як основних або додаткових навчальних предметів [8, с. 118]. Зокрема, в Університеті імені Ф. Шиллера в м. Єна студенти поглиблено вивчають ділову й економічну міжкультурну комунікацію. В Університеті Дюссельдорфа, де одним із перших у Німеччині був відкритий Інститут міжкультурної комунікації, головну увагу акцентують на практичному аспекті міжкультурної комунікації, більше часу приділяючи міжкультурним тренінгам, рольовим іграм і семінарам, що торкаються сорери міжнародних стосунків та бізнесу. У Кельнському університеті та Університеті м. Хемніц різні аспекти міжкультурної комунікації викладаються в контексті міграційної проблематики, а також питань міжкультурної освіти біженців та мігрантів. При цьому центральним аспектом міжкультурної освіти для всіх студентів, особливо майбутніх учителів іноземних мов, є вивчення специфріки взаємодії з представниками інших культур - їхніми майбутніми колегами, роботодавцями або клієнтами.
Ключовим аспектом подібних тренінгів і семінарів $€$ залучення не тільки німецьких, а й іноземних студентів університету [3, с. 42]. Подібні заходи дають змогу представникам різних культур безпосередньо взаємодіяти один з одним у рамках ігор і тренінгів, вчитися бачити подібності та відмінності культур, а також обговорювати найважливіші питання, що стосуються проблем і непорозумінь у галузі міжкультурної комунікації.

Семестр по обміну є обов'язковим для багатьох студентів педагогічного напряму підготовки, особливо для майбутніх учителів іноземних мов, оскільки навчання за кордоном розглядається невід'ємною частиною їхньої міжкультурної освіти в Німеччині. Можливість пройти стажування в університеті-партнері дає змогу не тільки поліпшити знання іноземної мови, а й більш глибоко й всебічно вивчити культуру країн «зсередини», мова яких вивчається [2, с. 231]. Через це принцип академічної мобільності вважається провідним у разі застосування міжкультурного підходу. Останній тлумачиться як нова парадигма професійно-педагогічної освіти, що спрямована на забезпечення професійного становлення майбутніх учителів іноземної мови як полікультурних багатомовних особистостей - медіаторів культур у сорері шкільної міжкультурної іншомовної освіти [3, с. 45].

Крім того, у великих Університетах Геттінгена, Гамбурга і Мюнхена з'являються наукові та освітні напрями під загальною назвою "Interkulturelles Lernen" («Міжкультурне навчання»), що займаються розглядом питань міжкультурної комунікації та її дидактичних аспектів у рамках здійснення завдань міжкультурної освіти для всіх громадян Німеччини. Навчальними планами цього напряму підготовки студентів передбачається вивчення питань, які стосуються способів подолання лінгвістичних проблем у системі освіти в межах концепції «мігрантської педагогіки», суть якої зводиться до організації адаптації дітей іноземців до нових реалій життя в чужій країні через освіту. Майбутніх учителів іноземних мов залучають до дослідження й оволодіння способами роботи з учнямимігрантами, враховуючи два контексти: інтеграцію іноземних дітей у культуру Німеччини як країни перебування; організацію роботи з підтримки культурних і мовних зв'язків 3 країною походження учнів-мігрантів [5, с. 52].

Одним 3 найважливіших засобів підготовки вчителів іноземних мов на засадах міжкультурного підходу німецькі фрахівці вважають міжкультурний тренінг. Ю. Больтен [1] та С. Ратье [7] виділили низку «мовних інтерактивних» складників, які, на їхню думку, мають бути невід'ємними складниками міжкультурного тренінгу майбутніх учителів. Серед них - усвідомлення залежності людського мислення, поведінки, способу дій, особливостей комунікативної поведінки від культурно специорічних 
концептів; здатність і готовність прийняти чужу перспективу (світогляд); знання параметрів, на основі яких можна розрізняти і порівнювати культури; спеціальне знання різних стилів комунікації і здатність ідентифрікувати такі стилі в комунікації; здатність до пояснення френоменів комунікативної дії і поведінки за допомогою закладених у них культурних детермінантів; розуміння основних принципів міжперсональної комунікації; оволодіння стратегіями іншомовної комунікації, а також стратегіями ідентифікації та аналізу комунікативних проблем на основі знань про культурні відмінності і їх вплив на поведінку і дії людей; використання мов міжнародного спілкування, забезпечення найкращих умов взаємодії за допомогою мовних засобів, уникнення комунікативних проблем і подолання непорозумінь [7, с. 232].

Загалом, німецькі вчені виділяють низку основних методів і підходів, які застосовуються в рамках міжкультурного тренінгу майбутніх учителів іноземної мови, серед яких:

- контрастивний метод, в якому за основу береться власна культура і здійснюється її порівняння 3 іншими, «чужими» культурами на основі культурних стандартів або політичних і соціальних норм поведінки [5, с. 37];

- дистрибутивний, або інструктивний підхід, в якому провідну роль приймає доповідач (викладач, студент), виступаючи «посередником» у процесі оволодіння міжкультурними знаннями $[4$, c. 38];

- інтерактивний метод, в основі якого лежить необхідність виконання тих чи інших дій студентами, що дає змогу їм краще пізнати й осмислити вплив власних і «чужих» культурних зразків поведінки, сприйняття, дій на перебіг ситуацій міжкультурного спілкування. При цьому аналізуються можливі непорозуміння і проблеми, а також відпрацьовуються стратегії для їх подолання в сорері міжкультурної освіти [10, с. 17];

- колаборативний метод на основі відкритих, проєктно-орієнтованих навчальних сценаріїв, до яких належать міжкультурні спільні проєкти, а також спільна робота в рамках міжкультурних зустрічей [8, с. 132].

Висновки і перспективи подальших досліджень. Таким чином, у працях прогресивно мислячих німецьких учених уперше міграція і зрос- тання культурного розмаїття стали розглядатися не як ризик, який слід долати, а як реальні ресурси духовного розвитку особистості сучасного європейця шляхом визнання загальнолюдських цінностей як універсальних. Упровадження міжкультурного підходу у процес професійної підготовки майбутніх учителів іноземних мов в університетах Німеччини сприяло набуттю ними готовності до розвитку в учнів міжкультурної толерантності й компетентності, фрормування почуття гідності та цінності власного народу (етнічної групи), виховання в дусі міжнаціонального гуманізму шляхом фрормування позитивного ставлення до носіїв інших культур, протидії всім формам ігнорування, ворожості, агресії та дискримінації.

\section{БІБЛІОГРАФІЧНИЙ СПИСОК:}

1. Bolten J. Interkulturelle Kompetenz. Erfurt: Landeszentrale für politische Bildung. 2012. 187 s.

2. Bonnet A., Breidbach S. Reflexion inszenierbar machen. Die Bedeutung der Bildungsgangforschung fur die Fremdsprachendidaktik. Sprachen lernen und lehren. Die Perspektive der Bildungsgangforschung. Munchen, 2007. S. 253-272.

3. Bosse E. Interkulturelle Qualifizierungsangebote für Studierende: mehrstufig, studienbegleitend und nachhaltig. Das Andere lehren. Handbuch zur Lehre Interkultureller Handlungskompetenz, 2010. S. 35-49.

4. Desch A. Pedagogik interkulturellen Lernens: Theorie und Praxis am Beispiel von internationalen Jugendbegegnungen. Marburg : Tectum Verlag, 2001. $136 \mathrm{~s}$.

5. Eubel-Kasper K. Fallstudien als Vehikel für interkulturelles Lernen: Ein Praxisbeispiel. Interkulturelle Kompetenz im Wandel: Ausbildung, Training und Beratung. Munster: LIT Verlag GmBH, 2011. S. 33-63.

6. Quality Assurance in Teacher Education in Europe. Eurydice. Brussels : Eurydice, 2006. 94 p.

7. Rathje S. Training/Lerntraining. Wie lehrt man interkulturelle Kompetenz? Theorien, Methoden und Praxis in der Hochschulausbildung. Ein Handbuch: Bielefeld, 2010. S. 215-240.

8. Scheitza A. Interkulturelle Kompetenz: Forschungsanstze, Trends und Implikationen für interkulturelle Trainings. Interkulturelle Kompetenz im Wandel, 2012. Band 1. S. 91-121.

9. UNESCO: Guidelines on Intercultural Education. Strasbourg: Council of Europe, 2006. URL: https:// unesdoc.unesco.org (дата звернення: 19.01.2020).

10. Wunram H., Dussap A. Methodeninventar für Interkulturelles Lernen. Haute-Alsace : NovaTris, 2015. $45 \mathrm{~s}$. 